\title{
Základní charakteristiky teologie dějin Josepha Ratzingera
}

\section{CTIRAD VÁCLAV POSPÍŠIL}

Jakmile vešlo ve známost, že papež Benedikt XVI. hodlá navštívit v září roku 2009 Českou republiku, vcelku pochopitelně to v naší vlasti vyvolalo vlnu zvýšeného zájmu o osobu tohoto svatého otce i o dílo světoznámého teologa Josepha Ratzingera. V dané souvislosti vznikl také tento příspěvek, jehož cílem je stručně připomenout základní body teologie dějin tohoto autora.

V první řadě je třeba velmi důrazně upozornit, že metodologicky není zcela korektní nerozlišovat mezi teologem Ratzingerem a papežem Benediktem XVI., jak se to ve světě editorie bohužel relativně často stává, když spisy Josepha Ratzingera po 19. dubnu 2005 zisku a senzace chtiví nakladatelé vydávají pod jménem Benedikta XVI. My se budeme zabývat teologií zmíněného autora, která však rozhodně nemá sama o sobě magisteriální povahu.

Téma teologie dějin jsem zvolil z několika důvodů. V první řadě proto, že v posledních letech vzniklé úvody do myšlení Ratzingera a přehledy jeho života se tímto tématem zabývají bud' jen částečně, neprímo, anebo vůbec. ${ }^{1} \mathrm{Ve}$ specializované studii věnované tématu teologie dějin v myšlenkovém odkazu dvacátého století se však setkáváme s velmi dobře zpracovanou kapitolou věnovanou Ratzingerovi. ${ }^{2}$ Dalším důvodem volby tohoto tématu je skutečnost, že právě téma teologie dějin či dějin spásy se stalo velmi aktuální v letech po skončení II. světové války, a proto se s ním Ratzinger musel vyrovnávat již od svých mladých let, o čemž svědčí jeho habilitační práce věnovaná teologii dějin sv. Bonaventury. Jelikož odpověd' na základní otázky spjaté s dějinami jako teologickým tématem značně ovlivňují nejen náš křestanský postoj ke světu, ale i samotnou metodu aplikovanou v teologii

1 Srov. VERWEYEN, Hansjürgen. Joseph Ratzinger - Benedikt XVI.: Die Entwicklung seines Denkens. 1. vydání. Darmstadt: Wissenschaftliche Buchgesellschaft, 2007 na stranách 114-134 se autor zabývá problematikou Ratzingerova politického myšlení, což lze hodnotit jako téma s teologií dějin spřízněné. ROWLAND, Tracey. Ratzinger's Faith: The Theology of Pope Benedict XVI. 1. vydání. New York: Oxford University Press Inc., 2008 - na stranách 105-122 autorka opět hovoří o Ratzingerově politickém myšlení. NICHOLS, Aidan. The Tought of Benedict XVI.: An Introduction to the Theology of Joseph Ratzinger. 1. vydání. New York: Burns \& Oates, 2005 - na stranách 51-65 se pojednává o Ratzingerově habilitační práci věnované teologii dějin sv. Bonaventury a na stranách 155-187 Nichols hovoří o Ratzingerově eschatologii.

2 Srov. PASQUALE, Gianliugi. La teologia della storia della salvezza nel secolo XX. 1. vydání. Bologna: EDB 2001, s. 133-156. 
samotné, mělo by být zřejmé, že se jedná o téma praktické a trvale aktuální, ${ }^{3}$ což platí i pro současnou českou teologii a její reflexi o sobě samé. ${ }^{4}$

$\mathrm{V}$ prvním bodě se zaměříme na problematiku poměru času a věčnosti a podkladem nám bude český překlad jedné studie Ratzingera a také jeho česky vydaná monografie o eschatologii. Ve druhém bodě se necháme týmž autorem poučit o poměru mezi teologií dějin na jedné straně a problematikou metody v teologickém myšlení na straně druhé. Třetí bod věnujeme ožehavému problému, jímž je poměr mezi soteriologií a politikou. Ve čtvrtém bodě stručně připomeneme Ratzingerovu studii o teologii dějin svatého Bonaventury z Bagnoregia. Nakonec připojím souhrnné hodnocení.

\section{1. Čas a věčnost}

První otázka, kterou musí řešit každý, kdo se začne zabývat teologií dějin, je problematika hodnocení času a jeho poměr $k$ věčnosti. Jestliže řecké myšlení stavělo čas a věčnost do jednoznačného protikladu a spása byla pojímána jako záchrana z času, pak křestanské myšlení jednak hodnotí čas pozitivně, protože se jedná o stvořenou záležitost, jednak nestaví věčnost a čas do ostrého protikladu. Ratzinger jasně odmítá pojímat věčnost jako atemporalitu, ne-časovost či bez-časovost, protože to podle něj nastoluje dualismus mezi naším světem a věčností. ${ }^{5}, V$ čase zraje to, co je víc než čas, takže konec času se stává také jeho naplněním."6 Po smrti člověk sice zakouší tajemnou definitivnost svého údělu, zároveň ale trvá určitá forma časovosti: „Člověk, který umírá, sám vystupuje z dèjin, jsou pro něj prozatím uzavřeny; neztrácí ale vazbu na dějiny, protože sít lidské relacionality patři k jeho podstatě.“7

S řečeným velmi úzce souvisí pojetí eschatologie, totiž zda ji máme vnímat jako prézentní, nebo futurální. Bultmannovo pojetí striktně prézentní eschatologie Ratzinger hodnotí jako únik z času, což je zcela pochopitelně nepřijatelné. ${ }^{8}$ Jako protipól k Bultmannově koncepci eschatologie je prezentován O. Cullmann, který klade velký důraz na dějiny a budoucnost. ${ }^{9}$ I zde se jedná

3 „Všechny oblasti lidské kultury procházejí proměnou kvůli problému bytí, které se stává historickým: ve filosofii tuto proměnu vidíme u Hegela, v ekonomii u Marxe, v teologii u Ferdinanda Christiana Bauera, v přírodní vědě je to, jak jsme již řekli, u Darwina.“ RATZINGER, Joseph. Natura e compito della teologia. 1. vydání. Milano: Ed. Paoline, 1993, s. 135.

4 Srov. POSPÍŠIL, Ctirad V. Teologie dějin a česká teologie. Teologické texty 2009, roč. 20 , č. 1 , s. 39-45.

5 Srov. RATZINGER, Joseph. O konci času: smrt, dějiny, věčnost: úvaha o největším tajemství. Mezinárodni katolická revue Communio 2002, roč. 6, č. 2 s. 115-129, zde s. 119.

6 Tamtéž, s. 129.

7 Srov. RATZINGER, Joseph. Eschatologie: smrt a věčný život. Brno: Barrister \& Principal, 1996, s. 110.

8 Srov. RATZINGER, Joseph. Eschatologie, s. 34-35.

9 Srov. tamtéž, s. 38-39. 
o určitou jednostrannost, protože eschatologie nepůsobí $\mathrm{v}$ přítomném čase, což není tak docela v souladu s Novým zákonem, kde se dozvídáme, že Kristus je nejenom po pravici Otce, tedy ve věčnosti, ale také s námi v čase (srov. např. Mt 28,20). Náš autor se podle všeho kloní ke koncepci C. H. Dodda, kde platí, že eschatologie je futurální i prézentní, jak to odpovídá svátostnému zpřítomňování: „Přítomnost toho, co se událo ve svátosti církve, otevírá ve spojení s oslaveným Pánem dveře řádu věčnosti, který je naším určením." 10

Na tomto místě si dovolím konstatovat, že tato paradoxální koncepce prézentní i futurální eschatologie se velmi blíží paradoxu „eschatologistický inkarnacionismus“, který zase ladí s ideálem „contemplativus in actione“.11

S pojetím času souvisejí také „geometrická schémata“. Velmi často se dnes setkáváme $s$ míněním, podle něhož řecké myšlení stavělo na kruhovém pojímání času, zatímco biblické myšlení má koncepci lineární (Cullmann). Celá věc je ale poněkud složitější. Kruhová koncepce času má také podobu schématu „egressus - regressus“, které je velmi silně př́tomno v teologii zejména velkých mistrů středověku a nalezli bychom ho rovněž v Bibli. ${ }^{12}$ Zde se ale rozhodně nejedná o bezcílné kroužení. Zejména u Bonaventury je patrné, že základem tohoto vyjití a návratu je vztah mezi Otcem a Synem. Čas je tedy $\mathrm{v}$ zásadě vztahová skutečnost a vychází z meziosobní diference $\mathrm{v}$ imanentní Trojici. Naproti tomu Aristotelés hájil linearitu plynoucího času, což jsme zvyklí připisovat biblické koncepci dèjin. Stojíme tudíž před velmi překvapivou inverzí schematických pojetí času. Základní diference mezi křestanským a řeckým přistupem tkví jednak v tom, že křestanská věčnost je charakterizována simultaneitou „ustavičného Ted““ ${ }^{13}$ jednak tím, že plynutí i „ustavičné Ted"“ se odehrávají v meziosobní vztahovosti. Zároveň je třeba důrazně podtrhnout, že křestanská aplikace schématu nevnímá „egressus“jako pád do konečnosti, materialisty a časovosti, nýbrž jako pozitivní stvořitelskou činnost Boží, pročež čas sám nemůže být čímsi negativním, ${ }^{14}$ jak již bylo konstatováno v bodu číslo jedna.

\section{Teologie dějin a nové pojetí teologie}

Jestliže evropské myšlení směřovalo po dlouhá staletí k tomu neměnné$\mathrm{mu}$, trvalému, k esenci, pak historické myšlení chce zachycovat bytí $\mathrm{v}$ jeho dějinné a časové dimenzi. $V$ křestanské teologii se napětí mezi děním

10 Tamtéž, s. 38.

11 Srov. POSPÍŠIL, Ctirad V. Teologie dějin a česká teologie.

12 Srov. POSPÍŠIL, Ctirad V. Soteriologie a teologie křiže Bonaventury z Bagnoregia. 1. vydání. Brno: Nakl. L. Marek, 2002, s. 167-206.

13 Srov. RATZINGER, Joseph. Der Mensch und die Zeit im Denken des heiligen Bonaventura: Zugleich ein Beitrag zum Problem des Mittelalterlichen Augustinismus. In DE RAEYMAEKER, Luis (ed.). L'homme et son destin d'après du Moyen Age. 1. vydání. Louvain - Paris, 1960, s. 473-483.

14 Srov. RATZINGER, Joseph. O konci času, s. 123-127. 
a esencí projevuje specificky jako polarita katolické christologie koncentrované na vtělení, přesněji řečeno na akt vtělení, což s sebou nese inklinaci k ontologii, zatímco protestantská teologie kladla velmi často vyhraněný důraz na dění, čemuž odpovídá pojetí teologie kříže ${ }^{15}$ :

„Idea dějin spásy se v moderní teologii objevuje jako protestantská antiteze katolického pojetí teologie zakládajícího se na ontologii. [...] Poněvadž pojem vtělení se jevil být opravdovým a vlastním zakotvením ontologie $\mathbf{v}$ teologii, byl proti tomu antiteticky postaven důraz na křižz, který je autentický výraz kristovského stávání se.“16

Opět je zřejmé, že jednostrannosti nejsou zdravé, a proto katolická teologie se musela otevřít dějovosti, příběhu Muže z Nazareta, ale nesměla ztratit ze zřetele ontickou dimenzi př́běhu, která tkví v osobní identitě Muže z Nazareta. Bez této identity se příběh rozpadá na kaleidoskop jednotlivých epizod, jejichž význam je velkou hádankou. Zkrátka a dobře, správné pojetí je opět paradoxální: jak akt vtělení, čili ontologie, tak teologie křiže, čili př́běh. To se projevuje v posledních desetiletích v tom, co nazýváme „narativní teologie“, která ve své vrcholné podobě nejenom otvírá ontologii dynamice času a příběhu, ale také vnímání jednotlivých událostí uvádí na jednotného společného jmenovatele osobní identity (ontologie). Ukazuje se totiž, že alternativa „nitro nebo dějiny“ vyplývá z výrazně povrchního pojetí dějin jako takových. Dějiny přece nejsou jenom vnější události bez lidské subjektivity jak aktérů onoho dění, tak interpretů oněch událostí. Zároveň se ukazuje, že pojetí dějin a času musí v teologii vycházet $\mathrm{z}$ christologie, protože $\mathrm{v}$ Ježíši Kristu vidíme tajuplné setkání a perichoretické prolnutí mezi věčností a časem. ${ }^{17}$

\section{Soteriologie a politika}

Dalším nesmírně důležitým tématem teologie dèjin je otázka, nakolik máme vlastními silami nastolovat na zemi Boží království. Jestliže je nepopiratelné, že se musíme zasazovat za lidštější svět a nasazovat se v projevování lásky potřebným, ${ }^{18}$ pak je zároveň nevyhnutelné uvědomovat si, že Boží království nikdy nesmíme redukovat jen na vnitrosvětskou záležitost, na dílo

15 „Theologia crucis“je výraz typický pro M. Luthera, který stavěl svou teologii křižze do ostrého protikladu k tak zvané „Theologia gloriae“. Teologie křiže je metodologická volba, která vnímá tajemství kříže jako vrchol zjevení, a proto také dnešní terminologií vyjádřeno jako hermeneutický klíč a architektonický princip celého teologického myšlení. Srov. POSPÍŠIL, Ctirad V. Teologie kříže a tajemství trpícího člověka. In MACHULA, Tomáš (ed.). Teologické studie. České Budějovice: Jihočeská univerzita v Českých Budějovicích - Teologická fakulta, 2000, s. 45-51.

16 RATZINGER, Joseph. Theologische Prinzipienlehre, s. 102-103.

17 Srov. RATZINGER, Joseph. Eschatologie, s. 113.

18 Srov. BENEDIKT XVI. Deus caritas est: encyklika z 25. 12. 2005. 1. vydání. Praha: Paulínky, 2006. 
našich rukou. Toto opomenutí transcendence a charakteru darovanosti Božího království nakonec vede $\mathrm{k}$ popření svobody člověka, $\mathrm{k}$ falešným mesianismům, před nimž výslovně varuje již sám Kristus, ${ }^{19}$ a v posledním důsledku k totalitarismům..$^{20}$ Nesmíme se proto divit, že Ratzinger se stavěl a staví velmi kriticky $\mathrm{k}$ jakékoli formě instrumentalizace křestanství ve smyslu nèkterých vyhraněných forem teologie osvobození. V posledním důsledku jde o vyváženost mezi spásou podle člověka (vnitrosvětský aspekt, inkarnacionismus) a spásou podle Boha (eschatologický prvek pojímaný futurálně a v transcendentním smyslu slova).

S tím, co jsme řekli, velmi úzce souvisí poměr mezi Duchem svatým a dèjinami. Ratzinger se jako pravovèrný katolík vymezuje proti imanentizaci a ideologizaci tajemství Ducha svatého, když důrazně prohlašuje, že Duch svatý je vzhledem k dějinám transcendentní. ${ }^{21}$ Uvážíme-li, jak silný vliv má zejména v německé myšlenkové oblasti, ale i mimo ni hegelovské pojetí dějin a Ducha, pak je tento Ratzingerův důraz velmi důležitým prvkem jeho myšlení, které se tak stává určitou formou vydávání svědectví.

„Jelikož exteriorita Ducha činí proroka racionálním, a nikoli iracionálním, pak také analogicky předjímavý pohled proroka na intimní vazbu mezi spravedlností člověka a novým světem Božím nevede ke kvietismu a k apolitické nečinnosti. Přesně naopak, právě skutečnost, že prorok ukazuje Boží království nikoli jako nějakou utopii, nýbrž jako Boží milost v teologickém slova smyslu, vede k tomu, že logicky zcela konsekventně tentýž prorok může požadovat spravedlnost jako politickou realitu." 22

Právě citovaná myšlenka rozhodně stojí za promyšlení a následné osvojení. Ona exteriorita Ducha vůči dění, čili Boží svoboda a transcendence, je kořenem naší svobody, a proto také nevede do falešné zátoky kvietismu ani do zhoubné náruče klamného utopismu, nýbrž přesně naopak v duchu vtělení nás má k reálnému, vtělenému, tedy prorockému nasazování se za spravedlnost $\mathrm{v}$ tomto světě, ovšem $\mathrm{v}$ pokoře, která nestaví výlučně na vlastním rozumu a na síle vlastních rukou, protože Boží království je právě díky oné exterioritě Ducha vůči dění svobodným obdarováním shůry. Díky tomu jsme nasazeni za lepší svět, ale zároveň jsme svobodni od sebe samých a svých vlastních koncepcí, a proto také otevřeni obdarování; svobodni od nutnosti uspět $\mathrm{v}$ našem počínání podle lidských měřítek, protože pravý úspěch tkví zejména v uchování otevřenosti našich myslí přicházejícímu obdarování.

19 Lk 21,8: „Dejte si pozor, abyste se nenechali svést! Mnozí (lidé) totiž přijdou pod mým jménem a budou říkat: „Já jsem to!“ a „Ten čas je tady!“ Nechod'te za nimi!“

20 Srov. RATZINGER, Joseph. Eschatologie, s. 39-40.

21 Srov. RATZINGER, Joseph. Alcune forme bibliche ed ecclesiali di „presenza“ dello Spirito nella storia. In SARTORI, L. (ed.). Spirito Santo e storia. 1. vydání. Roma, 1977, s. 51-55.

22 Srov. tamtéž, s. 55. 


\section{Bonaventurova teologie dějin}

Poté, co byl dne 29. 6. 1951 Joseph Ratzinger společně se svým bratrem Georgem vysvěcen na presbytera, směřoval nejprve k získání doktorátu teologie $\mathrm{v}$ roce $1953^{23}$ a posléze $\mathrm{k}$ habilitaci. Původně zamýšlel předložit práci věnovanou pojetí zjevení u sv. Bonaventury, ${ }^{24}$ nicméně posléze se habilitoval částí původně zamýšleného díla, totiž studií o Bonaventurově teologii dějin, jak se projevuje v posledním velkém díle tohoto mistra, jímž jsou slavné a v mnoha ohledech ne právě jasně srozumitelné Collationes in Hexaemeron. ${ }^{25}$

Proč právě toto téma? V první řadě proto, že se zde setkáváme s církevním učitelem, který se musel vyrovnávat s tehdy velmi populárními návrhy Jáchyma z Fiore ohledně nové periodizace dějin. Podle Jáchyma by totiž měla existovat doba Boha Otce - Starý zákon, doba Syna - novozákonní doba až do roku 1260 nebo 1290 (42 generací stejně jako Starý zákon), poté by měla nastat nová epocha, tedy doba Ducha svatého. Tato nauka vytvářela vcelku pochopitelně velké očekávání a $\mathrm{v}$ mnoha myslích také téměř nesnesitelné napětí, ba tíseň. Zároveň je třeba říci, že mnozí františkáni vztahovali Jáchymovu předpověd' z konce dvanáctého století o vzniku nového budoucího duchovního řádu na právě se zrodivší františkánské společenství. To vedlo $\mathrm{k}$ řadě excesů, pročež byla výrazně ohrožena existence františkánství i jeho dobré jméno v církvi. Jáchymova nauka ohledně tajemství Nejsvětější Trojice byla mimo jiné odmítnuta na IV. lateránském koncilu v roce 1215 . Nešlo ale o trojiční periodizaci dějin, nýbrž o Jáchymovu kritiku učení Petra Lombardského. Každopádně ale platí, že Jáchymova „epocha Ducha“ inspirovala všechny, kdo hlásali příchod nové epochy od 13. století až po století dvacáté. Zdá se, že právě zde se projevuje tendence k určité imanentizaci a ideologizaci Ducha, proti níž pak Ratzinger jako teolog i jako prefekt Kongregace pro nauku víry ostře vystupoval. Kořeny teologicko-politických postojů svatého otce jsou tedy hluboko $\mathrm{v}$ jeho mládí a v době jeho vědecké formace, o jejíž kvalitě svědčí kvalita plodů, jež dodnes přináší. Vratme se ale $\mathrm{k}$ samotné habilitační práci našeho autora.

Až zhruba do dvanáctého století bylo obvyklé tvrdit, že Kristus přišel na konci časů, nyní ale v souvislosti s přibývajícími staletími a také s Jáchymem z Fiore se profilovalo výrazně christocentrické pojetí, podle něhož by Kristus přišel uprostřed běhu dějin a jejich plnost by byla nyní vnímána $\mathrm{v}$ jistém slova smyslu kvalitativně, jak to vidíme u Bonaventury. ${ }^{26} \mathrm{~V}$ dané souvislosti roz-

23 Srov. RATZINGER Joseph. Volk und Haus Gottes in Augustins Lehre von Kirche. 1. vydání. St. Ottilien, 1992.

24 Srov. FRÝVALDSKÝ, Pavel. Christologie v díle Josepha Ratzingera: diplomová práce obhájená na Katedře fundamentální a dogmatické teologie KTF UK v Praze 2007, s. 11 (vyznamenaná Bolsanovou cenou).

25 Srov. italský překlad: RATZINGER, Joseph. San Bonaventura - la teologia della storia. 1. vydání. Firenze: Nardini editore, 1991.

26 Srov. BONAVENTURA. Breviloquium p. IV, c. IV, n. 5; český překlad: BONAVENTURA. Breviloquium: kompendium scholastické teologie. 1. vydání. Praha: Vyšehrad, 2004, s. 172. 
hodně není bez zajímavosti, že svatý Tomáš nikdy výslovně netvrdil, že Kristus by byl středem dějin. Nicméně Bonaventurova pozice je ve skutečnosti mnohem blíže Andělskému učiteli než Jáchymovi, protože Serafický doktor nikdy neučil, že by měla nastat nějaká třetí doba Ducha svatého. ${ }^{27}$

V Ratzingerově habilitační práci se setkáváme s celou řadou velmi zajímavých pasáží. Autor velmi plasticky mapuje jednotlivá schémata členění dèjin od patristické doby až po vrcholný středověk. Pozornost si zasluhuje také Ratzingerův poukaz na to, jak bylo u některých středověkých autorů pojímáno zjevení. Nešlo totiž tolik o objektivně vnímaný text Bible, nýbrž spíše o to, co při četbě Písma vyvolával v duši duchovního čtenáře Boží Duch. ${ }^{28}$ Stojíme před určitým napětím: subjekt a v něm působící Duch Boží ted' a tady na jedné straně a striktně objektivisticky, ba zvěcněle pojímané zjevení, které ploše identifikuje zjevení s literou Bible, na straně druhé. Stejně jako v př́ípadě dèjin je třeba ř́íci, že krajnosti vylučující opačný pól jsou nepřípustné. Jak dějiny, tak správná četba Písma mají fenomenickou povahu, z níž bychom nikdy neměli zcela vylučovat transcendentální složku. Díky tomu se naše pojetí zjevení otevře personálně dialogické dimenzi vztahu člověka a živého, pủsobícího Božího Ducha.

\section{Závěr}

Tato skromná připomínka některých základních rysů teologie dějin v díle Ratzingera by měla každého přesvědčit o tom, že se jedná o téma velmi důležité a v prŕpadě našeho autora zcela zásadní. $V$ Ratzingerově pojetí se setkáváme s pokusem o harmonické propojování celé řady polárních napětí, s nimiž se v teologii dějin setkáváme: objekt - subjekt; dèní - lidská mysl; transcendence - imanence Boha vzhledem ke světu a k dějinám... Pokud jde o politickou orientaci, je zřejmé, že Ratzinger je jasným obhájcem transcendence Ducha svatého vzhledem k dějinám, z čehož vyplývá, že křestan by se nikdy nemèl nechat dějinami pohltit a podlehnout nějaké ideologii. To ale rozhodně neznamená únik z dějin a rezignaci na úsilí o spravedlnost, lidskost a lásku v tomto čase. Výmluvně o tom vydávají svědectví prozatím dvě encykliky Benedikta XVI. Představení či připomenutí těchto záležitostí by si ale vyžadovalo samostatné pojednání.

27 RATZINGER, Joseph. San Bonaventura - la teologia della storia, s. 230.

28 Srov. tamtéž, s. 132-157. 